\title{
LOGGING AND TOPOGRAPHY EFFECTS ON ARTIFICIAL NEST PREDATION BY RATS IN LAUREL FORESTS
}

\author{
DELGADO, J.D. ${ }^{1} *$ - MoRALES, G. ${ }^{2}-$ ARROYO, N.L. ${ }^{3}-$ ARÉVALO, J.R. ${ }^{2}-$ \\ FERNÁNDEZ-PALACIOS, J.M. ${ }^{2}$ \\ ${ }^{1}$ Área de Ecología, Departamento de Sistemas Físicos, Químicos y Naturales, Universidad \\ Pablo de Olavide, E-41013, Sevilla, Spain \\ ${ }^{2}$ Departamento de Ecología, Facultad de Biología, Universidad de La Laguna, E-38206, Islas \\ Canarias, Spain \\ ${ }^{3}$ Universidad Pablo de Olavide, E-41013, Sevilla, Spain \\ *Corresponding author \\ e-mail: jddelgar@upo.es \\ (Received $26^{\text {th }}$ September 2011; accepted $7^{\text {th }}$ February 2013)
}

\begin{abstract}
We performed a general assessment of predation by rats (chiefly Rattus rattus) on artificial nests in context of vegetation structure at two subtropical laurel forests on Tenerife (Canary Islands). We selected two different types of forest stands (logged $v s$ unlogged) differing in vegetation pattern and conservation degree to test for the effect of logging on rat predation. We placed ground and tree nests on four plots per forest stand, each plot containing 40 nests ( 80 nests per treatment, 160 nests in all). We distributed nests among available sites with contrasting topography (plain areas, slopes, ridges and ravines). We tested for logging effects, topography and their interaction with survival analysis, comparing survival and hazard functions. We assessed the relationships between nest survival and vegetation structure with Cox survival regression. Vegetation structure was consistently different between slopes of logged (early successional) and unlogged (mature-like) forest. We found higher nest predation rates at the unlogged forest, in sloping areas, and in patches with dense tree canopy cover and an intermediate successional development. Rat nest predation on forest slopes (the dominant topographic landscape feature) was higher in mature (unlogged) than in early successional (logged) ones, suggesting that rats have adapted well to mature habitat and would prefer mature forest for foraging.
\end{abstract}

Keywords: vegetation structure, stand disturbance, laurisilva, birds, Rattus rattus

\section{Introduction}

Rats are a primary conservation concern for some threatened bird species (Atkinson, 1985; Taylor and Thomas, 1989; Clout et al., 1995; Innes, 2001; Thibault et al., 2002) and forest conservation on oceanic islands worldwide (Innes, 2001; Traveset et al., 2009). In the Canary Islands, ship rats (Rattus rattus) are the main predators of endemic fruit pigeons (Bolle's Laurel Pigeon Columba bollii and Laurel Pigeon C. junoniae), and probably of other birds, such as the ground-nesting Eurasian woodcock (Scolopax rusticola), the blackbird (Turdus merula) and others (Hernández et al., 1999; Martín and Lorenzo, 2001; Nogales el al., 2006).

Introduced ship rats realize a very generalist use of the laurel forest habitats (Delgado et al., 2001; Delgado, 2002), as it has been reported for forests elsewhere (e.g. Innes, 2001; Latham, 2006). Vegetation-abundance relationships and habitat type and fragmentation effects have been assessed for rats negatively affecting populations of breeding bird species (e.g. King et al., 1996; Matthews et al., 1999). In the Canaries, some research has been done on the relationships between general predation intensity by 
exotic rats and vegetation traits (Delgado, 2000, 2002; Delgado et al., 2001, 2005; Salvande et al., 2006).

Regarding ship rat ranging activity, they are well known for their arboreal habits, but they also explore and forage intensively on the ground in the Canary Islands and elsewhere. Previous studies in Canarian pine and laurel forests have detected high predation rates of baits on the ground (Delgado, 2000; Delgado et al., 2001; Hernández and Martín, 2003). Indirect effects of forest managing and wood extraction (disturbance of vegetation structure) may affect patterns of rat predation. Such knowledge would help to identify or envisage which forest areas will deserve more urgent, direct measures against introduced predators to reduce risks for endangered and other bird species.

In this paper, we assess the relationships between artificial nest predation by rats and habitat features at two contrasting types of laurel forests, one with a relatively high degree of conservation and continuity, and another that had experienced a great impact of forestry activities. In the latter, disturbance is represented by logging of exotic pine plantations to restore the native laurel forest on different years, plus subsequent logging of the secondarily grown native laurel forest. We evaluated relationships between survival functions and relative risk of artificial nest predation, and habitat (topography, vegetation structure, floristic composition and disturbance degree in both stand types). We tested whether predation rates differed between topographic sites (valley or ravine bottoms, slopes and ridges) in both logged and unlogged stands. We also studied the combined influence of topography and vegetation structure and floristics on nest survival and predation risk.

\section{Materials and methods}

\section{Study sites}

Field work was conducted at two laurel forest sites in northeast Tenerife, Canary Islands (Fig. 1). The two sites, lying $12 \mathrm{~km}$ apart, were Agua García-Las Lagunetas Protected Landscape (hereafter Agua García, or "AG" for brevity; coordinates: 28 27 ' $\left.\mathrm{N}, 16^{\circ} 24^{\prime} \mathrm{W}\right)$ and Anaga ( $\left.28^{\circ} 32^{\prime} \mathrm{N}, 16^{\circ} 17^{\prime} \mathrm{W}\right)$.

Anaga forests are included in the protected Anaga Rural Park, in a mountainous massif, whereas AG is in general a more leveled area. In both sites, canopy height, between 5-20 m, increases from ridge to ravine beds or valley bottoms, through slopes. Main tree species are Laurus azorica (Seub.) Franco, Myrica faya Aiton, Ilex canariensis Poir., Erica arborea L., E. platycodon (Webb and Berthel.) Rivas-Mart. et al., and Prunus lusitanica L. The bush layer is formed by Viburnum rigidum Vent., Hedera helix L., Rubus spp., Daphne gnidium L., Asplenium onopteris L., tree saplings and seedlings.

AG has been repeatedly cleared from original vegetation (laurel forest), planted with exotic Pinus radiata D. Don and Eucalyptus globulus Labill., species which were logged to allow recuperation of the native laurel forest. Native plants like Erica, Ilex, Viburnum and Laurus have been harvested for poles $(<5 \mathrm{~cm}$ diameter at breast height, dbh) for vineyard supports.

Anaga shelters some of the finest laurel forests on Tenerife, along with the Teno massive. Wood extraction is less severe in Anaga than in AG but still exist and mostly occurs along roads and footpaths, whereas ravine basins are better preserved. Noticeable secondary growth of laurel forest is taking place in abandoned agricultural terraces and paths. 


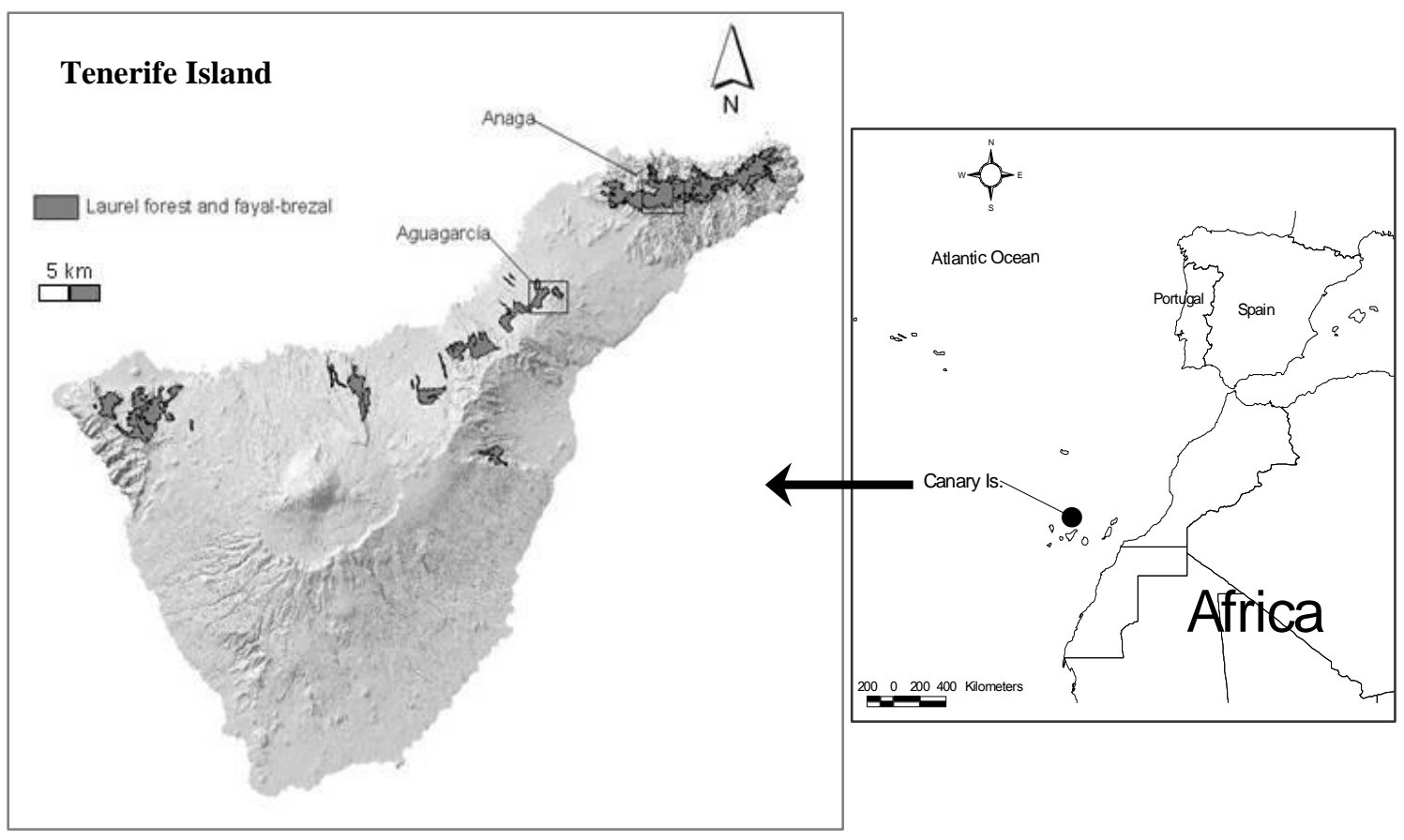

Figure 1. Location of the study sites

\section{Artificial nests}

We conducted the artificial nest predation trials in March and May 2001, in four replicate plots placed at both AG (logged forest) and Anaga (unlogged forest) (Appendix). On every of the four plots at each forest site, two $100 \mathrm{~m}$ transects (one 1-5 $\mathrm{m}$ from the road edge and the other $50 \mathrm{~m}$ to the forest interior) were constructed parallel to the road. On each transect we placed 20 nests, 10 on the ground under bushes or trees, and 10 on nearby trees at variable heights above ground (range: $0.5-4.5 \mathrm{~m}$; AG: $2.04 \pm 0.85$; Anaga: $1.56 \pm 0.37$ [mean $\pm \mathrm{SD}]$ ).

Overall, 160 nests were placed at both forests, 80 nests per forest site and 40 nests per plot. We placed half of all nests $(\mathrm{n}=80)$ on the ground and half on trees. Hardware mesh trays $(20 \times 15 \times 3 \mathrm{~cm})$ were filled with litter and baited with 3 quail eggs to represent the average clutch size of bird species at the study sites. Clutch size (number of eggs laid) per species were averaged from data in Martín and Lorenzo (2001). Nests were checked after 1, 3, 5, 10 and 20 days of exposure to predators. Nests surviving up to 25 days were noted as censored (not predated). Every inspection day we noted broken egg shells, tooth marks and droppings at or nearby the nests, in all cases being caused by rats. Nests were arranged $10-15 \mathrm{~m}$ apart on each transect to minimise spatial dependence on nest encounters in the study areas.

There is a justified scepticism about the validity of interpretations of actual predation from artificial nests (Major and Kendall, 1996). However, our use of artificial nests focused on comparing different areas subjected to contrasting treatments and vegetation. We kept constant the type and fabric of the nests, the type and number of eggs per nest, and the time of exposure to predators. We have evaluated a non-absolute but relative index of overall predation pressure (our response variable) which differs from actual predation. Regarding bird camouflaging strategies, we lack information on whether such mechanisms are efficient or not in throwing ranging rats off the scent, which are 
eminently olfactive and mostly nocturnal hunters. It has been suggested that lack of parental nest defence or camouflage (for example in the ground-nesting Scolopax rusticola) and higher conspicuousness of artificial nests can render higher rates of predation than for natural nests (King et al., 1999).

\section{Vegetation structure and diversity}

We characterized vegetation in a 5-m radius circle $\left(\sim 80 \mathrm{~m}^{2}\right)$ around each nest. Tree canopy closure was estimated with a spherical forest densiometer (Robert E. Lemmon, Bartlesville, OK, USA), by holding the densiometer at $1.5 \mathrm{~m}$ height and level $30 \mathrm{~cm}$ at right angle with the body. We counted the number of grid squares filled with canopy more than $75 \%$ (or $3 / 4$ ) of the area, and calculated the percentage of closure over the total number of squares.

We estimated canopy height visually to the nearest $2 \mathrm{~m}$ from four sectors of the $5 \mathrm{~m}$ radius circle, centered on each nest, and averaged the four measures. We visually estimated bush cover (including saplings of tree species and large ferns) and height, grass (or herbaceous plants including seedlings of tree species, grasses and small ferns), that can be used as measures of nest concealment (King et al., 1999), and percent litter cover.

We counted individual trees and woody plants, including vines and lianas, to obtain a measure of vegetation density. We sorted all individual higher plants within the plot by species to calculate floristic richness and diversity (Shannon's diversity, H').

Number of fleshy-fruited plant species was also recorded as an indirect measure of potential fruit resources exploitable by rats. Trees were sorted by diameter at breast height $(\mathrm{dbh}$, in $\mathrm{cm})$ into the following categories to record stem densities: $<5 ; 5-10 ; 10$ $20 ; 20-30 ;>30$ and all classes combined.

We counted the number of cut tree stumps to obtain a measure of selective wood harvesting intensity or logging. Stem density by dbh classes can be used as an indicator of forest structure and disturbance. Lower densities of thin shoots and trunks $(<20 \mathrm{~cm}$ $\mathrm{dbh}$ ) along with higher relative densities of thick, mature tree trunks $(>30 \mathrm{~cm})$ and tall canopy indicate mature-like forest conditions. The opposite structural pattern would indicate recently disturbed forest (i.e. intense resprouting, $<5 \mathrm{~cm} d b h$, low and sparse or shrubby canopy to selective pole harvesting and tree cutting).

\section{Statistical methods}

We used survival analysis (Muenchow, 1986; Fox, 1993) to test for differences between topographic habitat categories in survival and predation risk probabilities. We used the Kaplan-Meier procedure to compare survival curves among these categories, and applied the Breslow chi-square to test for significance (Fox, 1993). The topographic categories were: Agua García: a) Plain or level area, b) slope, and c) valley or ravine bottom; Anaga: a) Ridge, b) slope, and c) valley or ravine bottom.

We used Cox survival regression (Fox, 1993) to assess relationships between habitat structure and rate of artificial nest predation. The Cox's proportional hazards regression method for survival data can be used to test for the effect of a variable pool upon time till occurrence of an event (nest predation in this case). Variables used in the analysis as independent or predictors are specified in Appendix. Coefficients $(\beta)$ related to hazard and their standard errors, and Wald statistics (stepwise forward procedure) were computed for predictor variables. Variables significantly selected by the regression 
procedure entered the model below the 0.05 significance level. Negative $\beta$ coefficients related with a concrete habitat or predictor variable selected by the regression model indicate a higher mean survival and lower predation hazard; positive coefficients indicate higher hazard and lower mean survival times.

We could not assume complete independence of our predation data. The home range of ship rats can be larger than $100 \mathrm{~m}$, and thus the sampling scheme can be affected by spatial dependence. Runs tests performed on median cumulative hazard (impact, or predation risk) functions were calculated using the Monte Carlo procedure with 10.000 samples at the $99 \%$ confidence level. Runs tests suggested spatial dependence for ground predation in Anaga $(Z=-2.603, p=0.013)$, and both arboreal $(Z=-5.626, p<$ $0.001)$ and ground predation $(Z=-3.376, p=0.01)$ in $A G$. Arboreal predation in Anaga appeared to be spatially independent $(Z=-1.924, p=0.071)$.

All statistical analyses were performed with SPSS 12.0.

Table 1. Statistics of nest survival from the study sites. Estimation limited to largest survival time if censored (i.e. not predated)

\begin{tabular}{|c|c|c|c|c|c|c|c|}
\hline \multirow[b]{2}{*}{ Sites } & \multirow{2}{*}{\multicolumn{2}{|c|}{$\begin{array}{l}\text { Mean days } \\
\text { surviving } \\
\text { (1 SE) }\end{array}$}} & \multirow{3}{*}{$\begin{array}{c}\mathbf{9 5 \%} \\
\text { C.I. } \\
21.39-23.30\end{array}$} & \multirow{3}{*}{$\begin{array}{c}\begin{array}{c}\mathbf{N} \\
\text { nests }\end{array} \\
160\end{array}$} & \multirow{3}{*}{$\begin{array}{c}\begin{array}{c}\mathbf{N} \\
\text { predation } \\
\text { events }\end{array} \\
34\end{array}$} & \multicolumn{2}{|c|}{ Censored } \\
\hline & & & & & & $\mathbf{N}$ & $\%$ \\
\hline $\begin{array}{c}\text { Agua García } \\
\text { (logged) }\end{array}$ & 22.34 & $(0.49)$ & & & & 126 & $78.8 \%$ \\
\hline $\begin{array}{c}\text { Anaga } \\
\text { (unlogged) }\end{array}$ & 10.06 & $(0.72)$ & $8.66-11.47$ & 160 & 133 & 27 & $16.9 \%$ \\
\hline Overall & 16.20 & 0.55 & $15.12-17.29$ & 320 & 167 & 153 & $47.8 \%$ \\
\hline
\end{tabular}

\section{Results}

\section{Nest predation rates and topography}

Overall nest predation intensity was significantly higher in Anaga than in AG (Breslow $\chi_{1}^{2}=136.185, \mathrm{p}<0.001$; Table 1). Nests were predated at different rates depending on topographic places (Figure 2, Table 2). Hazard functions scored higher for Anaga than for AG, revealing higher risk of predation in the best-preserved area.

Table 2. Survivorship data for nests predated by rats depending on topography in Anaga and Agua García forests

\begin{tabular}{|c|c|c|c|c|c|c|}
\hline & \multicolumn{3}{|c|}{$\begin{array}{c}\text { Anaga } \\
\text { (unlogged stand) }\end{array}$} & \multicolumn{3}{|c|}{$\begin{array}{l}\text { Agua García } \\
\text { (logged stand) }\end{array}$} \\
\hline Topography & Ridge & Slope & $\begin{array}{l}\text { Ravine } \\
\text { bottom }\end{array}$ & Plain & Slope & $\begin{array}{l}\text { Ravine } \\
\text { bottom }\end{array}$ \\
\hline No. nests placed & 80 & 54 & 26 & 40 & 40 & 80 \\
\hline $\begin{array}{l}\text { No. predation } \\
\text { events }\end{array}$ & 67 & 45 & 21 & 12 & 1 & 21 \\
\hline No. nests censored & 13 & 9 & 5 & 28 & 39 & 59 \\
\hline $\begin{array}{l}\text { Percent of nests } \\
\text { censored }\end{array}$ & 16.30 & 16.70 & 19.20 & 70 & 97.5 & 73.8 \\
\hline $\begin{array}{c}\text { Mean survival } \\
\text { time } \pm 1 \text { SE (days) }\end{array}$ & $8.06 \pm 0.95$ & $10.33 \pm 1.27$ & $15.65 \pm 1.49$ & $22.63 \pm 0.73$ & $24.88 \pm 0.12$ & $20.94 \pm 0.87$ \\
\hline 95\% C.I. & $6.19-9.93$ & $7.85-12.82$ & $12.73-18.58$ & $21.20-24.05$ & $24.63-25.12$ & $19.24-22.64$ \\
\hline
\end{tabular}


Higher differences between topographic places were found in Anaga, and mean survival time was higher at ravine bottoms, decreasing through slopes and ridges (Breslow $\left.\chi_{2}^{2}=11.17, \mathrm{p}=0.001\right)$ (Table 2).

In $\mathrm{AG}$, there were no differences when comparing all three topographic categories (Breslow $\chi_{2}^{2}=0.285, \mathrm{p}=0.594$ ), although level and ravine bottom areas presented higher predation rates than slopes (Plain vs slope: Breslow $\chi_{2}^{2}=11.07, \mathrm{p}=0.001$; ravine vs slope: Breslow $\left.\chi_{2}^{2}=9.898, \mathrm{p}=0.002\right)$.
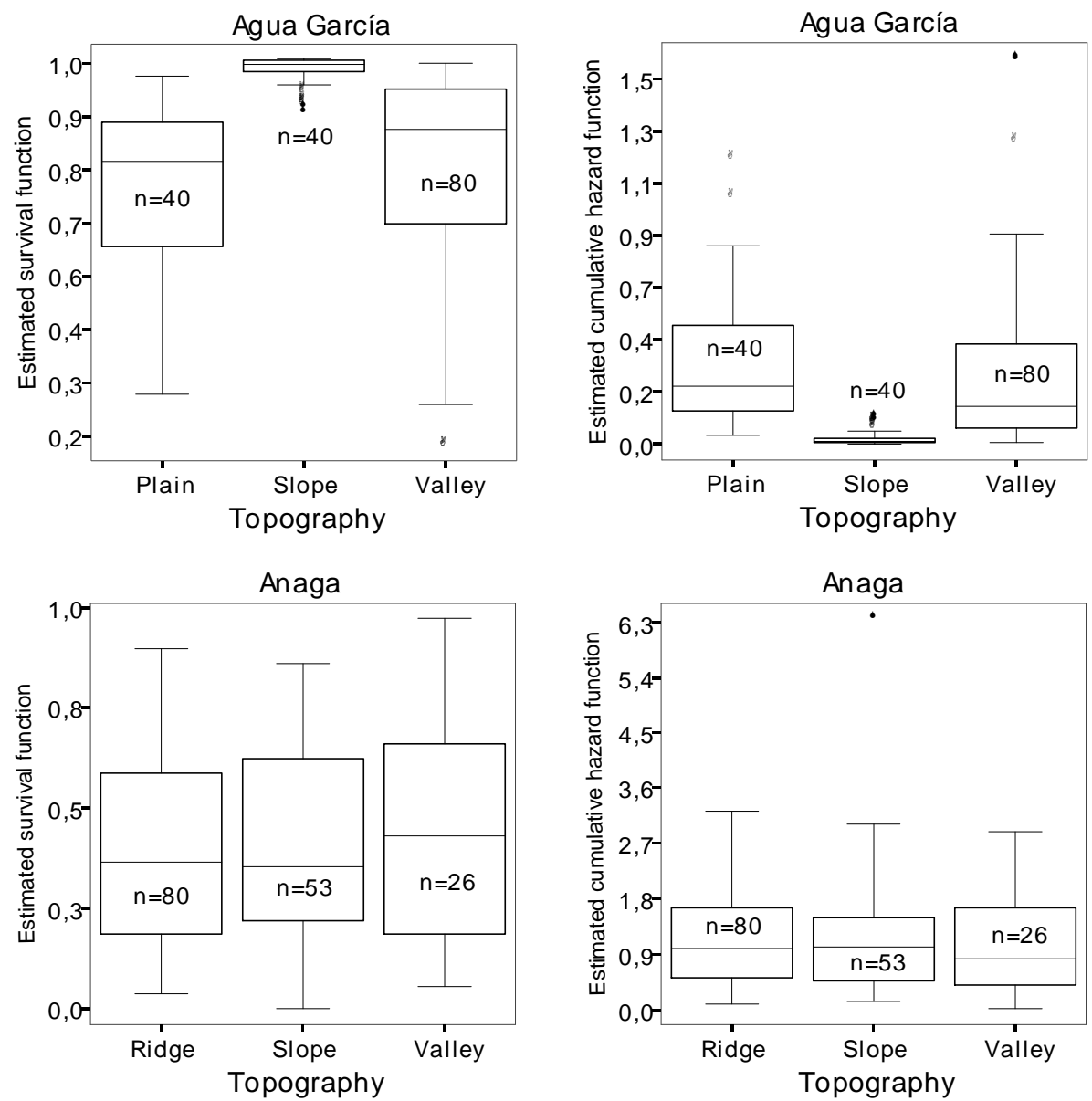

Figure 2. Influence of topography on predation. Survival and hazard functions estimated for the logged (Agua García) and unlogged (Anaga) sites. Shown are means, first and third quartiles, upper and lower values and outliers (open circles) and extreme values (asterisks)

\section{Vegetation structure and the topography pattern}

Main vegetation features of the two forests are compared in Fig. 3 among the different topographic places. Canopy cover was fairly continuous across topographic sites in the unlogged stand but it was very variable in the logged one. In both forests, canopy height increased from ridge or plains to ravine or valley bottoms. Plant species diversity and density of mature trees followed a similar trend from ridge to ravine bottoms in both forests. 

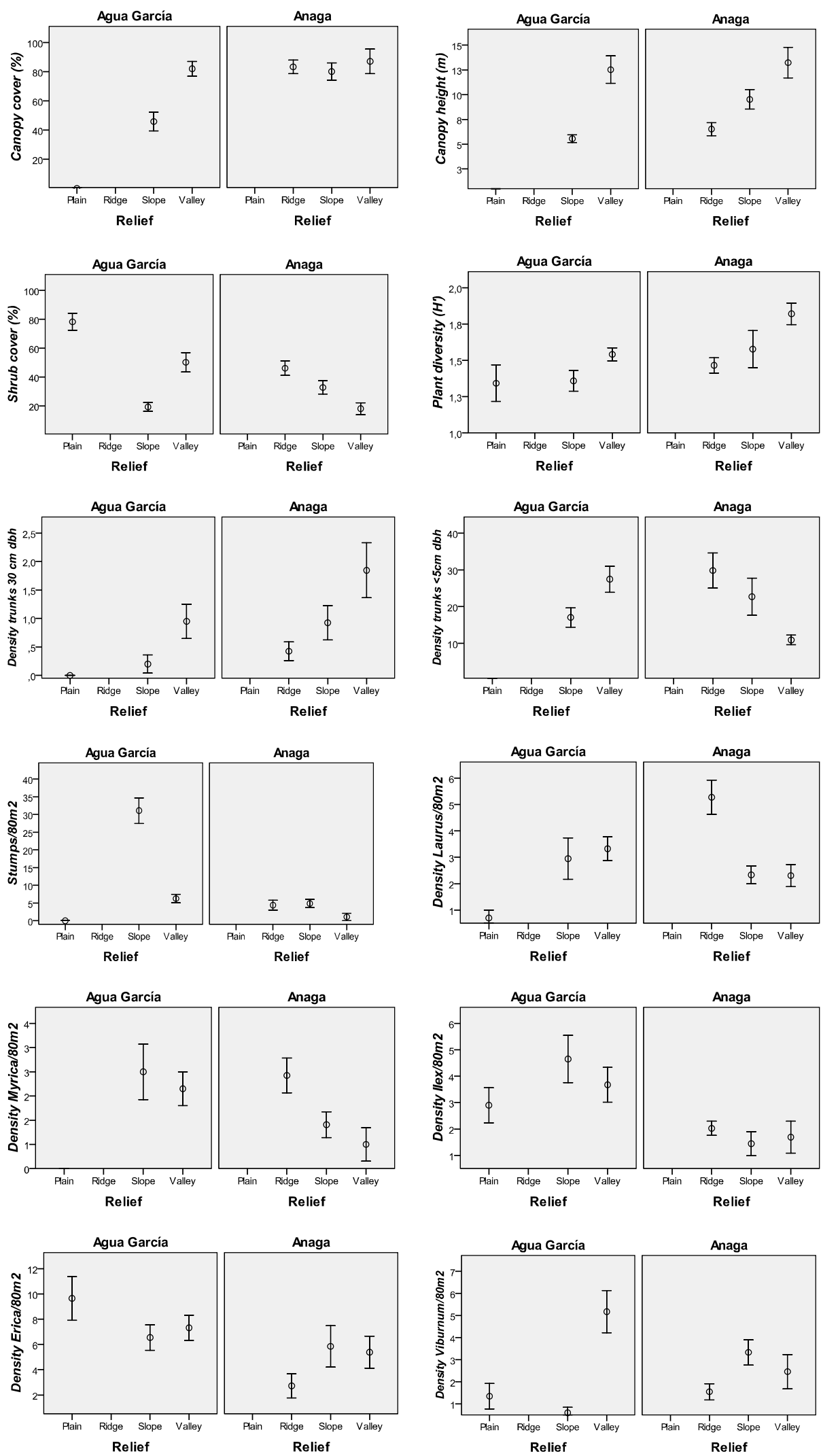

Figure 3. Vegetation structure traits as a function of topography in the logged (Agua García, $A G$ ) and unlogged (Anaga) laurel forest stands. Plain areas of $A G$ are replaced by ridge areas in Anaga. Means $\pm 1 S E$ are depicted 
The extent of forest concealing by increased suckling and sapling regrowth (trunks of dbh $<5 \mathrm{~cm}$ ), showed contrasting patterns (AG: Slope < Valley; Anaga: Valley < Slope < Ridge). Shrub density was more variable among the plots of the logged stand, but decreased clearly from ridge to slope to valley in the unlogged area. Density of Erica arborea and Ilex canariensis was generally higher in the logged stand, whereas densities of Laurus, Viburnum, or Myrica showed no clear differences. Canopy cover and height were significantly and positively correlated both in $A G(r=0.816, p<0.001)$ and in Anaga $(r=0.556, p<0.001)$, although the relationship was stronger for the first one.

The Figure 3 compares vegetation traits in the topographic situation with a lower predation rate in AG, namely "slopes" (only 1 predation event out of 40 nests; $97.5 \%$ censoring), with the analogous landscape element in Anaga (45 out of 54 nests, only $16.7 \%$ censoring). Sloping terrain, in a rugged ground such as that of the laurel forest on mountainous islands, is a prevalent landscape feature. Canopy cover and height, shrub cover, plant diversity, mature trees' density and Viburnum tinus (dominant fleshyfruiting shrub in the understorey) density, were consistently higher in slopes of Anaga than in AG (Fig. 3). On the contrary, density of Myrica faya, Ilex canariensis, and the index of selective wood extraction were higher in AG. This suggests that substantially lower predation intensity was taking place on the slopes at the structurally disturbed and impoverished laurel forest in AG.

\section{Survival regression analysis}

The Cox's proportional hazards regression performed on the untransformed set of predictor variables resulted in different models explaining predation patterns for Anaga and AG forests (Table 3). For the logged stand, the model included seven predictors. Three variables (canopy height, leaf litter cover and richness of fleshy fruit-producing plant species) had a negative relationship with predation, which means that they were related with comparatively higher survival (i.e. a "protective" effect). On the contrary, overall plant species richness, canopy cover, stem density (trunks $<5 \mathrm{~cm} \mathrm{dbh}$ ) and shrub cover had the opposite effect (i.e. related with higher nest predation rates).

Table 3. Outcome of the Cox's proportional hazards regression model (forward stepwise selection) for nest predation in relation with forest stand structure for the two sites. Only variables significantly selected by the model (at $P<0.05)$ were included

\begin{tabular}{l|c|c|c|c}
\hline \multicolumn{1}{c|}{ Sites } & \multicolumn{4}{c}{ Model statistics } \\
\hline \multicolumn{1}{c|}{ Agua García (logged) } & Coefficient $\beta$ & SE & Wald statistic & P $(\boldsymbol{\alpha}=\mathbf{0 . 0 5})$ \\
\hline Fruit species & -0.908 & 0.278 & 10.683 & 0.001 \\
Canopy height & -0.766 & 0.217 & 12.459 & 0.000 \\
Leaf litter cover & -0.022 & 0.009 & 5.826 & 0.016 \\
Plant species richness & 0.447 & 0.197 & 5.156 & 0.023 \\
Canopy cover & 0.039 & 0.012 & 9.605 & 0.002 \\
Density stems <5 cm dbh & 0.036 & 0.017 & 4.316 & 0.038 \\
Shrub cover & 0.022 & 0.008 & 6.874 & 0.009 \\
Anaga (unlogged) & & & & 0.000 \\
Canopy height & -0.688 & 0.117 & 34.704 & 0.000 \\
Density stems $\leq 20 \mathrm{~cm} \mathrm{dbh}$ & 0.133 & 0.028 & 22.689 & \\
\hline
\end{tabular}


Denser vegetation patches with a less mature structure, but still with some canopy cover, seemed to be associated to higher predation rates, whereas more open and sparse vegetation patches with less canopy cover were associated to lower predation rates.

In Anaga, only two variables were significantly included in the model. Canopy height revealed the same relationship with lower predation rates as in the logged area (i.e. "protective" effect), whereas higher stem density of trunks $<20 \mathrm{~cm}$ dbh (indicative of a maturing forest with an already developed canopy) was related with higher predation rates.

\section{Discussion}

In our study, rats showed: a) higher nest predation activity at the preserved, largely unlogged laurel forest stand (Anaga), which was in turn a topographically complex area, compared with the more levelled, and logged, AG stand; b) higher nest predation under dense and diverse, well developed tree canopy, but not under tallest canopies; c) different predation patterns across topographic places between an unlogged and a selectively logged forest area. Especially, nest predation by rats would be lower in sloping patches on intensely disturbed forest compared with similar inclination but in undisturbed habitat.

The impact of rat predation on artificial nests depended strongly on landscape configuration and vegetation structure resulting from forestry activities in laurel forest. Of our two study areas, the more mature and best-preserved stand (Anaga) has experienced moderate wood extraction in the recent past, and in most places secondary succession is very advanced and stand structure is that of a mature-like laurel forest, despite it still receives some selective harvesting. The AG stand, however, has been harvested very recently and intensity of wood extraction was still great and occurred all over the area (Appendix 1). How does this contrast in forest structure and disturbance level affects nest predation performance by ship rats, and how does it interact with topography?

If artificial nests represent convenient proxies for real nests, our results suggest that variation in topography within the forest masses could affect the risk of nest failure. Differences among topographic sites in nest predation rates are related with the inherent effect of landscape configuration on vegetation structure. Ravine bottoms are less exposed to wood extraction, soil is thicker and the forest acquires traits of a typical mature or older stand. On the contrary, slopes and plain or ridge areas are less developed, have a lower canopy, and a denser concealing of trees and shrubs, which is characteristic of stages of secondary regrowing and succession after cutting.

Rats can opportunistically select a wide variety of vegetation structures and habitat traits allowing them to attain huge population densities (Key et al., 1998). Rat prevalence can be high not only on well-preserved forest masses but also on disturbed ones. Ship rat densities in the Canarian laurel forest are amongst the highest recorded for island habitats (e.g. mature forest in La Gomera island, Contreras, 1988; compare with data from Amarasekare, 1993; Dowding and Murphy, 1994; Hooker and Innes, 1995; Sugihara, 1997; Martín et al., 2000; MacKay and Russell, 2005).

Rat density and activity can be limited following the disturbance caused by logging. As forest patches progress toward a mature-like structure after cutting, rat numbers would increase as habitat becomes less hostile (i.e. attraction from more fruit and animal food sources, coverage against predators and nesting sites) (see Boulton et al., 
2008). Some researchers have found higher ship rat density in patches of welldeveloped vegetation compared with areas where it is exposed to heavy disturbance (i.e. grazing, Innes et al., 2010). Ship rats have been found to be common in diverse forest habitats but rare in available open habitats (Cox et al., 2000). Dowding and Murphy (1994) detected lower ship rat densities in non-arboreal habitats. Innes (2001) have reported that ship rats are not affected by partial logging in podocarp-hardwood forests in New Zealand, but they were more abundant away from the road cleared edges, and on warmer and steeper (i.e. sloping) sites.

Despite that canopy cover and height were significantly correlated in our study, each variable can affect rat predation in different ways. Arboreality is an important habit in ship rats (Dowding and Murphy, 1994) which could direct its habitat selection among habitats with varied tree and shrub cover, and especially canopy height and accessibility (Latham, 2006). Density of trees of the most frequent species varied between both forest remnants and within forest depending on topography (Fig. 3). Efficiency of actions pursuing defence of native birds against rats would benefit of an evaluation of stand vegetation structure and of paying attention to the topography effect on rat habitat preferences. Further studies should assess the role of tree species characteristics and composition, and of rat selection of trees in rates of nest predation (Latham, 2006).

The higher heterogeneity among plots in the logged forest stand of Agua García would explain the larger number of variables to account for in the survival regression model. On the contrary, the plots at the unlogged Anaga stands were mostly of similar structure and composition (Appendix, Fig. 3), and smaller differences in nest predation were found among plots (Fig. 2).

We have found that artificial nest predation differed between both laurel forest remnants, with the higher overall risk of predation at the unlogged one. This result was similar to those of Dowding and Murphy (1994) and King et al. (1996), who trapped fewer ship rats in native, disturbed or early successional forest and non-forest sites, than in unlogged native forest. In our case, there can be also other causes which can influence our appreciation of rat predation that we cannot totally obviate, such as intrinsic differences in rat density, rat predators (i.e. nocturnal raptors, feral cats), general food availability for rats.

Regarding food availability, it is relevant that predation rates were lower in patches with a higher availability of fruiting trees (a proxy for potential fruit availability). It remains unclear for us, however, whether fruit species availability (which is not direct edible fruit availability) enhances or ameliorates rat predation intensity. Rats could select differentially rich fruiting areas for foraging, but large fruit availability could account for a comparatively lower impact of ship rats (largely frugivorous) on animal prey, depending on the season (see e.g. Martín et al., 2000). Rats eat other animal prey (i.e. invertebrates), which could be in turn associated to patches of laurel forest presenting a high diversity of fruiting trees (i.e. the endemic slugs of the genus Plutonia) (e.g. Hernández and Martín, 2003).

Acknowledgements. We thank Amagoia Olatz and Natalia Arroyo for helping in the field work and the Viceconsejería de Medio Ambiente del Gobierno de Canarias for supplying the traps and permits to work in the laurel forest. We thank also two anonymous referees for their improvements on a previous manuscript. 


\section{REFERENCES}

[1] Amarasekare, P. (1993): Potential impact of mammalian predators on endemic forest birds of Western Mauna Kea, Hawaii. - Conservation Biology 7: 316-324.

[2] Atkinson, I.A.E. (1985): The spread of commensal species of Rattus to oceanic islands and their effects on island avifaunas. - In: Moors, P.J. (ed.) Conservation of Island Birds. ICBP Technical Publication No. 3, pp 35-81.

[3] Boulton, R.L., Richard, Y., Armstrong, D.P. (2008): Influence of food availability, predator density and forest fragmentation on nest survival of New Zealand robins. Biological Conservation 141: 580-589.

[4] Clout, M.N., Karl, B.J., Pierce, R.J., Robertson, H.A. (1995): Breeding and survival of New Zealand pigeons Hemiphaga novaeseelandiae. - Ibis 137: 264-271.

[5] Contreras, M.J. (1988): Seguimiento de los micromamíferos del Parque Nacional de Garajonay, La Gomera. Resultados: noviembre 1987-noviembre 1988. La Laguna. Unpublished report. $10 \mathrm{pp}$.

[6] Cox, M.P.G., Dickman, C.R., Cox, W.G. (2000): Use of habitat by the black rat (Rattus rattus) at North Head, New South Wales: an observational and experimental study. Austral Ecology 25: 375-385.

[7] Delgado, J.D. (2000): Selection and treatment of fleshy fruits by the Ship Rat (Rattus rattus L.) in the Canarian laurel forest. - Mammalia 64: 11-18.

[8] Delgado, J.D. (2002): Interaction between introduced rats and a frugivore bird-plant system in a relict island forest. - Journal of Natural History 36: 1247-1258.

[9] Delgado, J.D, Arévalo, J.R, Fernández-Palacios J.M. (2001): Road and topography effects on invasion: edge effects in rat foraging patterns in two oceanic island forests (Tenerife, Canary Islands). - Ecography 24: 539-546.

[10] Delgado, J.D, Arévalo, J.R., Fernández-Palacios, J.M. (2005): Patterns of artificial nest predation by exotic rats in a fragmented subtropical forest (Tenerife, Canary Islands). Journal of Natural History 38: 2661-2669.

[11] Dowding, J.E., Murphy, E.C. (1994): Ecology of ship rats (Rattus rattus) in a Kauri (Agathis australis) forest in Northland, New Zealand. - New Zealand Journal of Ecology 18: 19-28.

[12] Fox, G.A. (1993): Failure-time analysis: emergence, flowering, survivorship, and other waiting times. - In: Scheiner, S.M., Gurevitch, J. (eds.) Design and analysis of ecological experiments Chapman and Hall, London, pp 253-289.

[13] Hernández, M.A, Martín, A. (2003): Efecto de Rattus Rattus sobre las Palomas Turqué (Columba bollii) y Rabiche ( $C$. junoniae): una experiencia de desratización en Tenerife. In: Rodríguez Luengo, J.L. (ed) Control de Vertebrados Invasores en Islas de España y Portugal. Consejería de Medio Ambiente y Ordenación Territorial del Gobierno de Canarias, pp 35-42.

[14] Hernández, M.A, Martín, A., Nogales, M. (1999): Breeding success and predation on artificial nests of the endemic pigeons Bolle's laurel pigeon Columba bollii and whitetailed laurel pigeon Columba junoniae in the laurel forest of Tenerife (Canary Islands). Ibis 141: 52-59.

[15] Hooker, S., Innes, J. (1995): Ranging behaviour of forest-dwelling ship rats Rattus rattus and effects of poisoning with brodifacoum. - New Zealand Journal of Zoology 22: 291304.

[16] Innes, J. (2001): Advances in New Zealand mammalogy 1990-2000: European rats. Journal of the Royal Society of New Zealand 31: 111-125.

[17] Innes, J., King, K.M., Bridgman, L., Fitzgerald, N., Arnold, G., Cox, N. (2010): Effect of grazing on ship rat density in forest fragments of lowland Waikato, New Zealand. - New Zealand Journal of Ecology 34: 227-232. 
[18] Key, G.E., Fielding, A.H., Goulding, M.J., Holm, R.S., Stevens-Woods, B. (1998): Ship rats (Rattus rattus) on the Shiant Islands, Hebrides, Scotland. - Journal of Zoology, London 245: 228-233.

[19] King, C.M., Innes, J.G., Flux, M., Kimberley, M.O., Leathwick, J.R., Williams, D.S. (1996): Distribution and abundance of mammals in relation to habitat in Pureora Forest Park. - New Zealand Journal of Ecology 20: 215-240.

[20] King, D.I., DeGraaf, R.M., Griffin, C.R., Maier, T.J. (1999): Do predation rates on artificial nests accurately reflect predation rates on natural bird nests? - Journal of Field Ornithology 70: 257-262.

[21] Latham, J. (2006): The ecology of ship rats (Rattus rattus) on Ponui Island: implications for North Island brown kiwi (Apteryx mantelli). - MSc Thesis, University of Auckland, New Zealand.

[22] MacKay, J.W.B., Russell, J.C. (2005): Eradication of ship rats from Goat Island AprilOctober 2005. Unpublished report to the Department of Conservation. - University of Auckland: 13 pp.

[23] Major, R.E., Kendal, C.E. (1996): The contribution of artificial nest experiments to understanding avian reproductive success: a review of methods and conclusions. - Ibis 138: 298-307.

[24] Martín, A., Lorenzo, J.A. (2001): Aves del Archipiélago Canario. - Lemus, Tenerife.

[25] Martín, A., Hernández, M.A., Lorenzo, J.A., Nogales, M., González, C. (2000): Las palomas endémicas de Canarias. - Consejería de Política Territorial y Medio Ambiente de Canarias, SEO-Birdlife, Tenerife.

[26] Matthews, A., Dickman, C.R., Major, R.E. (1999): The influence of fragment size and edge on nest predation in urban bushland. - Ecography 22: 349-356.

[27] Muenchow, G. (1986): Ecological use of failure time analysis. - Ecology 67: 246-250.

[28] Nogales, M., Rodríguez-Luengo, J.L., Marrero, P. (2006): Ecological effects and distribution of invasive non-native mammals on the Canary Islands. - Mammal Review 36: 49-65.

[29] Salvande, M., Mulet, M., Gómez, L.A. (2006): Ilex canariensis Poir. (Aquifoliaceae) post-dispersal seed predation in the Canary Islands. - Plant Ecology 187: 143-151.

[30] Sugihara, R.T. (1997): Abundance and diets of rats in two native Hawaiian forests. Pacific Science 51: 189-198.

[31] Taylor, R.H., Thomas, B.W. (1989): Eradication of Norway rats (Rattus norvegicus) from Hawea Island, Fiordland, using brodifacoum. - New Zealand Journal of Ecology 12: 2332.

[32] Thibault, J-C., Martin J-L., Penloup, A., Meyer, J-Y. (2002): Understanding the decline and extinction of monarchs (Aves) in Polynesian Islands. - Biological Conservation 108: 161-174.

[33] Traveset, A., Nogales, M., Alcover, J.A., Delgado, J.D., López, M., Godoy, D., Igual, J.M., Bover, P. (2009): A review on the effects of alien rodents in the Balearic (Western Mediterranean Sea) and Canary Islands (Eastern Atlantic Ocean). - Biological Invasions 11: 1653-1670. 
Appendix 1. Vegetation structure of study plots at Agua García (logged) and Anaga (unlogged) sites. Stand age is only given for the Agua García plots (managed area) and it refers to years after cutting or main disturbance (exploitation or managing) to the year 2001 (see methods for details). Figures represent means \pm 1 sd and range (in parentheses). $N=20$ sampling points per plot

\begin{tabular}{|c|c|c|c|c|c|c|c|c|c|c|}
\hline $\begin{array}{c}\text { Agua } \\
\text { García } \\
\end{array}$ & $\begin{array}{c}\operatorname{Age}^{\mathrm{a}} \\
(\mathbf{y}) \\
\end{array}$ & \multicolumn{2}{|c|}{ Regime } & \multicolumn{2}{|c|}{$\begin{array}{c}\text { Canopy } \\
\text { cover }(\%)\end{array}$} & \begin{tabular}{|c|c|} 
Canopy \\
height $(\mathrm{m})$
\end{tabular} & $\begin{array}{c}\text { Shrub } \\
\text { cover }(\%)\end{array}$ & $\begin{array}{c}\text { Shrub } \\
\text { height }(\mathbf{m})\end{array}$ & $\begin{array}{c}\text { Grass } \\
\text { cover }(\%)\end{array}$ & $\begin{array}{l}\text { Leaf litter } \\
\text { cover }(\%)\end{array}$ \\
\hline Plot 1 & 13 & \multicolumn{2}{|c|}{$\begin{array}{c}\text { Past } \\
\text { selective } \\
\text { harvesting }\end{array}$} & \multicolumn{2}{|c|}{$\begin{array}{c}83.5 \pm 21.4 \\
(29.3-99)\end{array}$} & $\begin{array}{c}11.2 \pm 3.5 \\
(6-18)\end{array}$ & $\begin{array}{c}65.5 \pm 18.2 \\
(30-90)\end{array}$ & $\begin{array}{c}2.4 \pm 0.5 \\
(1.5-3)\end{array}$ & $\begin{array}{c}24.4 \pm 18 \\
(5-65)\end{array}$ & $\begin{array}{c}92.3 \pm 15.1 \\
(50-100)\end{array}$ \\
\hline Plot 2 & 41 & \multicolumn{2}{|c|}{$\begin{array}{c}\text { Past } \\
\text { selective } \\
\text { harvesting }\end{array}$} & \multicolumn{2}{|c|}{$\begin{array}{c}80.5 \pm 25.3 \\
(38.6-99)\end{array}$} & $\begin{array}{c}13.9 \pm 8.2 \\
(0-25)\end{array}$ & $\begin{array}{c}35 \pm 33.4 \\
(0-90)\end{array}$ & $\begin{array}{c}2.2 \pm 0.6 \\
(1-3.5)\end{array}$ & $\begin{array}{c}15 \pm 13.8 \\
(0-40)\end{array}$ & $\begin{array}{c}80.8 \pm 21.5 \\
(25-100)\end{array}$ \\
\hline Plot 3 & 1 & \multirow{2}{*}{\multicolumn{2}{|c|}{$\begin{array}{l}\text { Undergoin } \\
\text { g selective } \\
\text { harvesting } \\
\text { Clearcut } \\
\text { (pine } \\
\text { removal) }\end{array}$}} & \multicolumn{2}{|c|}{$\begin{array}{l}45.8 \pm 21 \\
(0.2-75)\end{array}$} & $\begin{array}{c}5.6 \pm 1.2 \\
(4-8)\end{array}$ & $\begin{array}{c}19.3 \pm 10 \\
(5-35)\end{array}$ & $\begin{array}{c}1 \pm 0.4 \\
(0.3-1.7)\end{array}$ & $*$ & $\begin{array}{c}66.5 \pm 24.6 \\
(10-95)\end{array}$ \\
\hline Plot 4 & $2-3$ & & & \multicolumn{2}{|l|}{$*$} & $*$ & $\begin{array}{c}78.3 \pm 19.1 \\
(30-100)\end{array}$ & $\begin{array}{l}1.8 \pm 0.2 \\
(1.5-2)\end{array}$ & $\begin{array}{c}23.3 \pm 21.8 \\
(0-70)\end{array}$ & $\begin{array}{c}13.5 \pm 13.6 \\
(0-40)\end{array}$ \\
\hline \multicolumn{11}{|l|}{ Anaga } \\
\hline Plot 1 & $?$ & & $X$ & \multicolumn{2}{|c|}{$\begin{array}{l}74.8 \pm 27.8 \\
(26.2-99)\end{array}$} & $\begin{array}{l}10.6 \pm 5.1 \\
(3.5-20)\end{array}$ & $\begin{array}{c}23.5 \pm 16.1 \\
(5-65)\end{array}$ & $\begin{array}{c}1.7 \pm 0.4 \\
(0.8-2.5)\end{array}$ & $\begin{array}{l}7 \pm 8.3 \\
(0-30)\end{array}$ & $\begin{array}{c}61.8 \pm 27.9 \\
(15-95)\end{array}$ \\
\hline Plot 2 & $?$ & & $X$ & \multicolumn{2}{|c|}{$\begin{array}{l}84.6 \pm 26.1 \\
(12.6-100)\end{array}$} & $\begin{array}{c}8.9 \pm 4.9 \\
(3-16)\end{array}$ & $\begin{array}{c}32.5 \pm 20.5 \\
(5-85)\end{array}$ & $\begin{array}{c}1.8 \pm 0.2 \\
(1.5-2.2)\end{array}$ & $\begin{array}{c}4.3 \pm 5.2 \\
(0-20)\end{array}$ & $\begin{array}{c}67.3 \pm 22.7 \\
(25-95)\end{array}$ \\
\hline Plot 3 & $?$ & & $\mathrm{X}$ & \multicolumn{2}{|c|}{$\begin{array}{c}83.8 \pm 17.1 \\
(42.8-97.9)\end{array}$} & $\begin{array}{l}6.1 \pm 2.6 \\
(3-9.5)\end{array}$ & $\begin{array}{c}45 \pm 27(5- \\
80)\end{array}$ & $\begin{array}{c}1.8 \pm 0.3(1- \\
2.5)\end{array}$ & $\begin{array}{c}25.3 \pm 20.9 \\
(5-80)\end{array}$ & $\begin{array}{c}73.5 \pm 24.5 \\
(10-100)\end{array}$ \\
\hline Plot 4 & $?$ & & $X$ & \multicolumn{2}{|c|}{$\begin{array}{c}88.1 \pm 10.7 \\
(61.5-97.9)\end{array}$} & $\begin{array}{c}8.9 \pm 2.5 \\
(5-14)\end{array}$ & $\begin{array}{c}47.3 \pm 15.4 \\
(20-75)\end{array}$ & $\begin{array}{l}1.8 \pm 0.2 \\
(1.5-2)\end{array}$ & $\begin{array}{c}0.5 \pm 1.5 \\
(0-5)\end{array}$ & $\begin{array}{c}84.5 \pm 10.1 \\
(60-100)\end{array}$ \\
\hline $\begin{array}{l}\text { Agua } \\
\text { García }\end{array}$ & \multicolumn{2}{|c|}{$\underset{\text { density }^{b}}{\text { Stump }^{\text {and }}}$} & \multicolumn{2}{|c|}{$\begin{array}{c}\text { Density stems } \\
<5 \\
\text { cm dbh }\end{array}$} & \multicolumn{2}{|c|}{$\begin{array}{c}\text { Density stems } \\
(5-10] \mathrm{cm}^{-} \\
\text {dbh }^{\mathbf{b}}\end{array}$} & $\begin{array}{c}\text { Density } \\
\text { stems } \\
(10-20] \text { cm } \\
\text { dbh }^{\mathbf{b}} \\
\end{array}$ & $\begin{array}{c}\text { Density } \\
\text { stems (20- } \\
30] \mathrm{cm} \mathrm{dbh}^{\mathbf{b}}\end{array}$ & $\begin{array}{c}\text { Density } \\
\text { stems } \\
>30 \\
\text { cm dbh }^{\text {b }}\end{array}$ & \begin{tabular}{|c} 
Plant \\
diversity \\
$\left(H^{\prime}\right)$
\end{tabular} \\
\hline Plot 1 & \multicolumn{2}{|c|}{$\begin{array}{c}4.9 \pm 5.1 \\
(0-16)\end{array}$} & \multicolumn{2}{|c|}{$\begin{array}{c}33.2 \pm 10.7 \\
(11-60)\end{array}$} & & $\begin{array}{c}5.8 \pm 2.2 \\
(1-9)\end{array}$ & $\begin{array}{c}3.2 \pm 2.1 \\
(0-8)\end{array}$ & $\begin{array}{c}0.3 \pm 0.6 \\
(0-2)\end{array}$ & $*$ & $\begin{array}{l}1.5 \pm 0.2 \\
(1-1.7)\end{array}$ \\
\hline Plot 2 & \multicolumn{2}{|c|}{$\begin{array}{c}7.6 \pm 5.8 \\
(0-17)\end{array}$} & \multicolumn{2}{|c|}{$\begin{array}{c}21.7 \pm 19.1 \\
(1-61)\end{array}$} & & $\begin{array}{c}3.1 \pm 2.1 \\
(0-8)\end{array}$ & $\begin{array}{c}2.6 \pm 1.5 \\
(0-5)\end{array}$ & $\begin{array}{c}1.6 \pm 1.6 \\
(0-5)\end{array}$ & $\begin{array}{c}0.6 \pm 0.9 \\
(0-3)\end{array}$ & $\begin{array}{l}1.6 \pm 0.2 \\
(1.3-2)\end{array}$ \\
\hline Plot 3 & \multirow{2}{*}{\multicolumn{2}{|c|}{$\begin{array}{c}31.1 \pm 11 \\
8(18-53) \\
*\end{array}$}} & \multirow{2}{*}{\multicolumn{2}{|c|}{$\begin{array}{c}17.1 \pm 8.5 \\
(4-36) \\
*\end{array}$}} & & $\begin{array}{l}3.6 \pm 3 \\
(1-10)\end{array}$ & $\begin{array}{c}1.5 \pm 1.5 \\
(0-6)\end{array}$ & $\begin{array}{c}0.2 \pm 0.5 \\
(0-2)\end{array}$ & $*$ & $\begin{array}{c}1.4 \pm 0.2 \\
(0.8-1.7)\end{array}$ \\
\hline Plot 4 & & & & & & $*$ & $*$ & $*$ & $*$ & $\begin{array}{c}1.3 \pm 0.4 \\
(0.7-2) \\
\end{array}$ \\
\hline \multicolumn{11}{|l|}{ Anaga } \\
\hline Plot 1 & \multicolumn{2}{|c|}{$\begin{array}{c}3.7 \pm 4.8 \\
(0-15)\end{array}$} & \multicolumn{2}{|c|}{$\begin{array}{c}20.5 \pm 20.6 \\
(4-74)\end{array}$} & & $\begin{array}{c}3.9 \pm 3.1 \\
(0-9)\end{array}$ & $\begin{array}{c}3.2 \pm 2.7 \\
(0-8)\end{array}$ & $\begin{array}{c}1.5 \pm 1.4 \\
(0-5)\end{array}$ & $\begin{array}{c}0.5 \pm 0.6 \\
(0-2)\end{array}$ & $\begin{array}{c}1.5 \pm 0.5 \\
(0.5-2.2)\end{array}$ \\
\hline Plot 2 & \multicolumn{2}{|c|}{$\begin{array}{c}1.3 \pm 2.1 \\
(0-7)\end{array}$} & \multicolumn{2}{|c|}{$\begin{array}{c}13.4 \pm 6.6 \\
(5-31)\end{array}$} & & $\begin{array}{c}3 \pm 2.2 \\
(0-8)\end{array}$ & $\begin{array}{c}3.4 \pm 2.4 \\
(0-7)\end{array}$ & $\begin{array}{c}0.7 \pm 1.1 \\
(0-4)\end{array}$ & $\begin{array}{c}0.4 \pm 0.6 \\
(0-2)\end{array}$ & $\begin{array}{c}1.6 \pm 0.2 \\
(1.2-2)\end{array}$ \\
\hline Plot 3 & \multicolumn{2}{|c|}{$\begin{array}{c}7.3 \pm 7.8 \\
(0-21)\end{array}$} & \multicolumn{2}{|c|}{$\begin{array}{c}41.1 \pm 25.1 \\
(9-77)\end{array}$} & & $\begin{array}{c}7.6 \pm 3.7 \\
(1-14)\end{array}$ & $\begin{array}{c}4.4 \pm 3.7 \\
(0-12)\end{array}$ & $\begin{array}{c}0.4 \pm 0.6 \\
(0-2)\end{array}$ & $\begin{array}{c}0.1 \pm 0.2 \\
(0-1)\end{array}$ & $\begin{array}{c}1.4 \pm 0.2 \\
(1.1-1.8)\end{array}$ \\
\hline Plot 4 & \multicolumn{2}{|c|}{$\begin{array}{c}3.8 \pm 3.5 \\
(0-11)\end{array}$} & \multicolumn{2}{|c|}{$\begin{array}{c}22.4 \pm 11.9 \\
(2-41)\end{array}$} & & $\begin{array}{c}8.8 \pm 4.4 \\
(3-20)\end{array}$ & $\begin{array}{c}6.4 \pm 3.2 \\
(2-12)\end{array}$ & $\begin{array}{c}0.7 \pm 0.9 \\
(0-3)\end{array}$ & $\begin{array}{c}0.1 \pm 0.3 \\
(0-1)\end{array}$ & $\begin{array}{l}1.8 \pm 0.2 \\
(1.4-2)\end{array}$ \\
\hline
\end{tabular}

${ }^{\text {a }}$ Age since the last major disturbance or silvicultural treatment (only in Agua García) (Morales et al. 1996; Cabildo de Tenerife. Sección de Montes).

${ }^{\mathrm{b}}$ stump and stem density by dbh classes are expressed as no. stumps $80 \mathrm{~m}^{-2}$.

* variable had zero values in the plot 